The Gene Revolution and Global Food Security 
Also by Banji Oyelaran-Oyeyinka and Padmashree Gehl Sampath

LATECOMER DEVELOPMENT: Innovation and Knowledge for Economic Catch-up

Also by Banji Oyelaran-Oyeyinka

UNEVEN PATHS OF DEVELOPMENT (with Rajah Rasiah)

INDUSTRIAL CLUSTERS AND INNOVATION SYSTEMS IN AFRICA:

Institutions, Markets and Policy (with Dorothy McCormick)

SMES AND NEW TECHNOLOGIES: Learning E-Business and Development (with Kaushalesh Lal)

LEARNING TO COMPETE: Institutions, Technology and Enterprise in Africa Also by Padmashree Gehl Sampath

UNHEALTHY DIVIDE: Local Capacity for Disease of the Poor

REGULATING BIOPROSPECTING: Institutions for Access and Drug Research 


\section{The Gene Revolution and Global Food Security}

\section{Biotechnology Innovation in Latecomers}

Banji Oyelaran-Oyeyinka

Director, Monitoring and Research Division, UN-HABITAT

Padmashree Gehl Sampath

Research Fellow, United Nations University-MERIT 


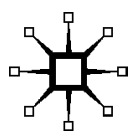

C) Banji Oyelaran-Oyeyinka and Padmashree Gehl Sampath 2009

Softcover reprint of the hardcover 1st edition 2009 978-0-230-22882-5

All rights reserved. No reproduction, copy or transmission of this publication may be made without written permission.

No portion of this publication may be reproduced, copied or transmitted save with written permission or in accordance with the provisions of the Copyright, Designs and Patents Act 1988, or under the terms of any licence permitting limited copying issued by the Copyright Licensing Agency, Saffron House, 6-10 Kirby Street, London EC1N 8TS.

Any person who does any unauthorized act in relation to this publication may be liable to criminal prosecution and civil claims for damages.

The authors have asserted their rights to be identified as the authors of this work in accordance with the Copyright, Designs and Patents Act 1988.

First published 2009 by

PALGRAVE MACMILLAN

Palgrave Macmillan in the UK is an imprint of Macmillan Publishers Limited, registered in England, company number 785998, of Houndmills, Basingstoke, Hampshire RG21 6XS.

Palgrave Macmillan in the US is a division of St Martin's Press LLC, 175 Fifth Avenue, New York, NY 10010.

Palgrave Macmillan is the global academic imprint of the above companies and has companies and representatives throughout the world.

Palgrave ${ }^{\circledR}$ and Macmillan ${ }^{\circledR}$ are registered trademarks in the United States, the United Kingdom, Europe and other countries

ISBN 978-1-349-31024-1

ISBN 978-0-230-27799-1 (eBook)

DOI 10.1057/9780230277991

This book is printed on paper suitable for recycling and made from fully managed and sustained forest sources. Logging, pulping and manufacturing processes are expected to conform to the environmental regulations of the country of origin.

A catalogue record for this book is available from the British Library.

A catalog record for this book is available from the Library of Congress.

$\begin{array}{llllllllll}10 & 9 & 8 & 7 & 6 & 5 & 4 & 3 & 2 & 1\end{array}$

$\begin{array}{llllllllll}18 & 17 & 16 & 15 & 14 & 13 & 12 & 11 & 10 & 09\end{array}$ 
For

Fola, Banke, Koye

and

Nisha 
This page intentionally left blank 


\section{Contents}

List of Boxes $\quad \mathrm{x}$

List of Figures $\quad$ xi

List of Tables xii

Preface xiv

Acknowledgements $\quad$ xvii

1 Agricultural Biotechnology Innovation Capacity and

Economic Development $\quad 1$

1.1 Introduction 1

1.2 Agricultural innovation and the promise

1.3 Defining biotechnology and articulating agriculture biotechnology 6

1.4 Building agricultural biotech capacity for food security and poverty reduction 12

1.5 Innovation capacity: Institutional basis of variations across countries 15

1.6 Innovation capacity: Nature and definition 19

1.7 Innovation policies and innovation capacity 22

$\begin{array}{ll}1.8 \text { Methodology } & 24\end{array}$

2 Sectoral Systems for Agricultural Biotechnology 27

$\begin{array}{ll}2.1 \text { Introduction } & 27\end{array}$

2.2 Applying innovation systems framework to late $\begin{array}{ll}\text { development } & 28\end{array}$

2.3 Agricultural biotechnology as a sectoral system of innovation 36

$\begin{array}{ll}2.4 \text { Knowledge bases } & 47\end{array}$

2.5 Interactive learning and innovation capacity at the sectoral level in latecomers $\quad 50$

2.6 Rough road to the market 56

2.7 The role of the state in promoting agricultural biotechnology 60

$\begin{array}{ll}2.8 \text { Summing up } & 65\end{array}$ 
3 Malaysia Biotechnology: A Fast Follower 67

3.1 Introduction 67

3.2 Key actors generating agriculture innovations and knowledge 68

3.3 Science, technology, and innovation investments 71

3.4 Interactive learning and collaboration 80

3.5 The role of the state in promoting agricultural biotechnology $\quad 85$

$\begin{array}{ll}3.6 \text { Summing up } & 87\end{array}$

4 Vietnam Biotechnology: Building Local Capacity 89

4.1 Introduction $\quad 89$

4.2 The nature and base of knowledge activities 92

4.3 Science, technology, and innovation (STI) investments 93

4.4 Survey results: Employment, domestic inputs and R\&D staff over the period 2001-5 96

4.5 Key actors and organizations and their roles in the sector 99

4.6 Survey results: Institutions and incentives for innovation 105

4.7 Interactive learning in the biotechnology system 108

4.8 State policies and regulatory framework for biotechnology development 109

$\begin{array}{ll}4.9 \text { Summing up } & 112\end{array}$

5 Nigeria as a Very Late Follower in Agricultural Biotechnology 117

5.1 Introduction 117

5.2 Key actors generating agriculture biotechnology
innovations and knowledge

5.3 Science, technology, and innovation (STI) investments 122

5.4 Interactive learning and collaboration 126

5.5 The role of policy and the state in enabling a Sectoral System of Innovation (SSI) for agricultural biotechnology 131

5.6 Case study: The cassava success in Nigeria 135

5.7 Summing up 139

6 Kenya's Incipient Innovation Capacity in Biotechnology 141

6.1 Introduction 141

6.2 Key actors generating agricultural biotech
innovation and knowledge

6.3 Science, technology, and innovation investments 147

6.4 Interactive learning 151 
6.5 The role of the state in promoting agricultural biotechnology

6.6 Case study: The Kenyan cut flower sector 166

6.7 Summing up

7 Comparative Analysis of Innovation Capacity in

Latecomer Countries

7.1 Introduction

7.2 Knowledge bases to promote the Green and Gene Revolutions

7.3 Science technology and innovation investment

7.4 Interactive learning in agricultural biotechnology: What matters and what not?

7.5 Rough road to the market: The limitations of infrastructure and dedicated policy instruments

7.6 The role of state capacity and policy vision

7.7 Agricultural innovation capacity, food security, and poverty reduction: A look at the broader implications

8 Policy Insights and Recommendations 205

8.1 Introduction

8.2 Delineating development across continents: Policy insights for agricultural innovation in Asia and Africa

8.3 Endogenous capacity for GM crops in Africa 


\section{List of Boxes}

1.1 Past contributions of science and technology 8

1.2 Biotechnology, food security, and poverty 10

1.3 Plant variety protection and biosafety regimes in latecomers 21

3.1 Clustering biotechnology initiatives: Bionexus Malaysia 76

5.1 Organizations engaged in biotechnology research in Nigeria 123

6.1 Genetic Technologies International Laboratories (GTIL) Limited 


\section{List of Figures}

1.1 FAO Food Price Index, 2000-8 9

1.2 Characteristics of the Green and 'Gene' Revolutions 17

1.3 Latecomer capabilities for agricultural biotechnology 18

2.1 Capabilities formation for agricultural biotechnology within latecomers

2.2 Biotechnology sectoral system of innovation in developing countries

2.3 Institutions supporting collaborative learning in agricultural biotechnology

2.4 Illustrative graph of the financial demand of scaling R\&D outputs and/or invention

3.1 Funding allocation to biotechnology in Malaysia 74

3.2 Percentage biotechnology share of GDP (projected) 75

3.3 Business accelerator programmes in key focus areas $\quad 76$

3.4 Mean employment over the period 2001-5 78

3.5 Mean domestic inputs over the period 2001-5 79

3.6 Mean R\&D expenditures and R\&D personnel over the period 2001-5 79

4.1 Mean employment over the period 2001-5 98

4.2 Mean domestic inputs over the period 2001-5 98

4.3 Mean R\&D expenditures and R\&D personnel over the period 2001-5 99

6.1 Components of the agricultural biotechnology innovation system in Kenya 148

7.1 Measuring innovation capacity in latecomers 172

7.2 Regional per hectare fertilizer use 180

7.3 Percent of people living under US $\$ 1.00$ per day 201

7.4 Prevalence of undernourishment in developing countries 202

$\begin{array}{lll}7.5 & \text { Population of people living under US\$1.00 per day } 202\end{array}$

7.6 Proportion of population living below poverty (1980-2005) 204

7.7 Regional Urbanization Trend (1980-2005) 204 


\section{List of Tables}

2.1 Mainstream economics and evolutionary theory: Issues for characterizing innovation capacity

2.2 Policy capacity for agricultural biotechnology

3.1 Research institutions and universities engaged in biotechnology work

3.2 BCCs of relevance to agriculture biotechnology

3.3 Descriptive statistics of employment, domestic inputs, and R\&D over the period 2001-5

3.4 ML estimates of R\&D expenditures

3.5 Correlation between the types of collaboration

3.6 The role of government incentives in new product and new process development: $\mathrm{t}$ - and z-tests

3.7 Execution and implementation strategies

4.1 Descriptive statistics of employment, domestic inputs, and R\&D over the period 2001-5

4.2 ML estimates of the dynamic panel data

4.3 Universities in Vietnam providing biotechnology programme

4.4 Institutions and incentives for innovation:

Descriptive statistics

4.5 Probit estimation results and marginal effects: New product development

4.6 Descriptive statistics of employment, domestic inputs and R\&D over the period 2001-5

4.7 Correlation between the types of collaboration

5.1 Biotechnology tools and areas of work: Results of the 2003 survey

5.2 Descriptive statistics: Innovation, learning, and government policies and funding

5.3 Descriptive statistics: Technological performance and networking

5.4 Foreign and local collaborations

5.5 Biotechnology programmes in Nigeria

5.6 Actors configuration, activities, and constraints

5.7 Area of focus of cassava actors

6.1 The state of tissue culture in Kenya as of 1998 
6.2 Collaborators and partners in the sweet potato project

6.3 Status of modern biotechnology (genetic modification) projects in Kenya, 2006

6.4 Current agricultural biotechnology projects in Kenya (2006) 145

6.5 School enrolment ratios, Kenya 2000-5

6.6 Financial support to entrepreneurial activity, Kenya

6.7 Investment and R\&D

6.8 Biotechnology and biosafety policy development timeline in Kenya

7.1 Comparative enrolment of countries

7.2 Skilled personnel engaged in agricultural biotechnology in Malaysia, Vietnam, and Nigeria

7.3 Productivity of the oil palm sector in Malaysia and Nigeria

7.4 Biotechnology infrastructure in selected Eastern African countries (2003)

7.5 Biotechnology human resource capacity status in selected East African countries (2003)

7.6 Bivariate probit estimates: Nigeria innovation capacity factors

7.7 Sources of technology for product development in biotechnology firms in Malaysia and Vietnam

7.8 Nature of innovation products in all four countries

7.9 Policies, laws, and regulations relevant to biotechnology in Kenya

7.10 Ownership of oil plantation in Malaysia and Nigeria 


\section{Preface}

This book is set against the backdrop of the debate about the persistent poverty of developing countries - those we have differentially labelled latecomer countries - as well as the widening divide in income per capita rather than the convergence of income that was predicted several decades ago. Equally germane to the debate about latecomer poverty and growing inequality between the rich and the poor countries is the ever-widening gap between the scientific and technological capabilities of latecomer countries and the 'frontier' advanced industrial nations. Underlying these debates is considerable confusion about what precisely the role of states may be in the economic advancement of those countries that have developed and the enduring poverty of those that remain at the bottom of the ladder. This book argues that those who advocate a neutral role for state industrial and innovation policy tend to engage in rhetoric that does not fit the facts of the history of Western societies and simply ignores the contemporary lessons of East Asia. The current triune global challenge, namely, the food crisis, fuel and climate concerns, and the housing crisis has renewed the discussion about the form, nature, and direction of participation in business and society.

This book benefits from our collective involvement in the field of industrial, scientific, and technological policy for more than three decades both as practitioners and as researchers. It is in fact our experiences in different countries in Africa and Asia working, researching, and interviewing all manner of actors such as large-scale farmers, industrialists, and small enterprise owners that prompted this book as well as other companion books in which we have been engaged. The research and outputs thereby suggested to us to seek - with others - that the most urgent issue for these times is to formulate some answers and possible prescriptions to the persistent latecomer economic backwardness.

Beginning with the concepts of the processes we call variously 'technology transfer', 'technology capability acquisition', and so forth, from the 1970s the notion of innovation entered the lexicon of the process of development now referred to as 'catching-up' by latecomers. In the six years we spent at the UNU-INTECH, we led several research projects (interviewing dozens of firms) in attempting to understand the root of technology-based and industry-based 
underdevelopment. This endeavour led to several books and articles in academic journals, including one recently published and another forthcoming book. ${ }^{1}$

These experiences led us to three sets of conclusion: first, rich countries built strong institutions as complements to productive systems (frontier as well as emerging), and in so doing, became rich through production and exporting of high quality goods and services; poor countries remain poor because they continue to produce raw materials for the relatively rich countries. Second, central to the production activities of all countries that became rich is a set of policies that we may classify as industrial or innovation policies even when the rhetoric of rich countries does not square with the reality as exemplified by the set of ideas embodied in the so-called Washington Consensus (WC). In other words, rich countries do precisely what benefits their industries at every historical turn and continue to advise poor countries to do what benefits rich countries. The 'strong' poor countries (India, China, and much of East Asia earlier on) deployed Industrial and Innovation Policies (IIP) for the benefit their economies while the 'weak' poor countries (much of sub-Saharan Africa (SSA) and the other Asian countries) listen to variants of advice embodied in the WC and subsequently remain poor. This variant of the WC was precisely what the Structural Adjustment Programme (SAP) was about in the 1980s. This set of 'one size fits all' policies replaced many of the (admittedly more complex) emerging industrial policies in SSA with a simplistic macro-economic framework that led to the de-industrialization of the embryonic economies of SSA. The third broad conclusion is that poor countries require industrial and innovation policies that shift productive attention from raw materials production to materials processing using the best technologies (in economic terms, structural transformation for turning out high-quality products) available. These technologies also result in a rise in labour productivity (rising output per worker). We have defined what we understand by these terms in the book and, more importantly, we believe the set of ideas guiding what we term innovation capacity should be linked to the traditional issues of development economics because solving the poverty problem engendered by the endemic low productivity regimes of production in very latecomers will have to reckon with building innovation capacity underpinned by contextspecific institutions and policies.

We argue that latecomer countries need to build innovation capacity for three key reasons, namely: to promote strong interactive learning among productive and non-productive actors; to foster greater information and 
knowledge flow, and, lastly, to enhance the coordination of policies and actors. Undertaking these three is a complex task and this has been the usual argument against industrial policy: that is, governments are unable to allocate resources through bureaucratic mechanisms and are in any case too corrupt and lack the incentive to work towards public purpose. In short, advocates of the alternative systems argue that IIP is too complicated and complex for latecomers in Asia and Africa to engage in. Two sets of issue raised by critics of IIP are: first, a lack of incentive for good bureaucratic behaviour, and second, the state in latecomer countries is unable to substitute for information coordination due to its highly decentralized nature. We consider this argument unconvincing because the same case can be made to support the establishment of mechanisms, organizations, and institutions for education, health, roads, and so on in the form of ministries and agencies.

The plethora of myths about markets as well as new and important evidence on the role of the state reinforce the need for a rethink of what the role of the government should be in creating dynamic innovation policies in a global system that has become more complex, knowledgebased, and innovation-driven. These are the ideas that we put forward in making a case for a redoubling of efforts in latecomer countries to deploy biotechnology in solving both the poverty problem and the food crisis in poor countries. 


\section{Acknowledgements}

The idea of embarking on a research project to compare the biotechnology systems of innovation in African and Asian countries arose out of some of our earlier work on the topic, as well as the curiosity to find new data on issues so pertinent to sustainable development among latecomers. We are grateful to IDRC, Canada for funding the project which led to the research results contained in this book. Field surveys in latecomer countries on topics such as these are impossible and incomplete without the assistance of committed local researchers. We acknowledge and thank all our consultants in Vietnam, Malaysia, Nigeria, Tanzania, Ghana, and Kenya who helped conduct the empirical surveys. Our special thanks go to Wladimir Raymond, Erika Moran, Graciela van der Poel, Eveline in the Braek from UNU-MERIT, and Nelly Kangethe from UNHABITAT for research assistance at different stages of book production. Last but not least, we thank Rosemund and Dirk for their neverending support and patience, especially in accommodating the hectic travel schedules that this book necessitated. 